\title{
Agnieszka Haska
}

Instytut Filozofii i Socjologii PAN

https://orcid.org/0000-0003-0545-5250

ahaska@ifispan.edu.pl

\section{„Choć klimat jest dobry..." Polscy Żydzi internowani na Jamajce w latach 1942-1945}

\begin{abstract}
Streszczenie
Artykuł stanowi wprowadzenie do historii polskich Żydów, którzy na skutek porozumienia rządów polskiego i brytyjskiego w 1942 r. trafili na Jamajkę, gdzie przebywali w obozie internowania Gibraltar Camp. W drodze na Jamajkę towarzyszyło im wyobrażenie, że jest to miejsce, gdzie będą mogli w miarę normalnie żyć i pracować. Rzeczywistość okazała się rozczarowująca, czemu internowani dawali wyraz w opublikowanych w załączeniu listach, wysyłanych do Ignacego Schwarzbarta, członka Rady Narodowej Rzeczypospolitej Polskiej na obczyźnie.
\end{abstract}

\section{Słowa kluczowe}

polscy Żydzi, uchodźcy, Jamajka, Gibraltar Camp

\begin{abstract}
The article is an introduction to the history of Polish Jews who, as a result of the agreement of the Polish and British Governments in 1942, landed in Jamaica, where they were placed in the in the Gibraltar internment camp. On their way to Jamaica, they were were under the impression that was the place where they could live and work as normally as possible. But the reality turned out to be disappointing, something that was reflected in letters of the interned which were sent to Ignacy Schwarzbart attached to this text, member of the National Council of the Republic of Poland in exile.
\end{abstract}

\section{Key words}

Polish Jews, refugees, Jamaica, Gibraltar Camp

Mimo że w ostatnich latach wzrasta zainteresowanie losami żydowskich uchodźców, którzy różnymi sposobami uciekli z okupowanej Polski lub znaleźli się poza jej granicami przed wybuchem wojny i próbowali dzięki wizom różnych państw wyjechać z Europy, to wciąż temat ten w polskiej literaturze przedmiotu nie doczekał się kompleksowych opracowań - i to nawet w kontekście pomocy udzielanej przez polskie placówki dyplomatyczne. Jednym z mniej znanych epizodów tej historii jest kwestia internowania polskich Żydów w brytyjskich 
obozach tworzonych w koloniach, m.in. w Beau Bassin na Mauritiusie i Camp Gibraltar na Jamajce. 0 ile w pierwszym przypadku internowanymi byli żydowscy uchodźcy z Europy (1580 osób, w tym 172 osoby legitymujące się polskim obywatelstwem), którzy w 1940 r. próbowali nielegalnie przedostać się do Palestyny i trafili na Mauritius w konsekwencji brytyjskiej polityki ograniczania napływu imigrantów na teren Mandatu ${ }^{1}$, o tyle internowani na Jamajce znaleźli się tam na skutek porozumienia rządów polskiego i angielskiego ${ }^{2}$. Po upadku Francji wiosną 1940 r., w związku z napływem do neutralnej Portugalii uchodźców legitymujących się polskimi paszportami, polskie MSZ oraz Poselstwo RP w Lizbonie badało możliwości otrzymania wiz pozwalających na wyjazd do innych krajów, m.in. Kanady, Brazylii czy RPA. Wiosną 1941 r. rząd portugalski zaostrzył kurs wobec uchodźców, przedstawiając im wezwania do opuszczenia kraju w ciągu 30 dni, a w przeciwnym razie kierując do obozów internowania ${ }^{3}$. Równolegle polskie MSZ podjęło rozmowy z rządem brytyjskim i amerykańskim o ewakuacji około 200 polskich Żydów, aby nie zaogniać trudnych stosunków z Portugalczykami. Problemem były pieniądze na przejazd, wizy wjazdowe oraz zadeklarowanie kosztów utrzymania na miejscu. Jako miejsce pobytu dla tej grupy rozważano Kubę oraz - po otrzymaniu zgody władz brytyjskich - Jamajkę ${ }^{4}$. Koszty - początkowo przez rok - zgodził się pokryć Joint ${ }^{5}$.

24 stycznia 1942 r. na pasażerskim parowcu s/s Serpa Pinto z Lizbony do Kingston znalazła się pierwsza grupa 152 polskich Żydów; w sumie w $1942 \mathrm{r}$. na Jamajkę trafiły 184 osoby legitymujące się polskimi paszportami ${ }^{6}$. Byli wśród nich ludzie różnych zawodów i z różnymi biografiami - od tzw. diamenciarzy z Antwerpii, przez inżynierów, fabrykantów, przedsiębiorców, aż do drobnych rzemieślników czy krawcowych. Część z nich - jak matka nastoletniego Manfreda (Freda) Manna, autora wspomnień A Drastic Turn of Destiny - wyjechała z Polski na długo przed wojną i ich polskie obywatelstwo, które prawnie utracili ustawą z 31 marca 1938 r., zostało jednak po wybuchu wojny potwierdzo-

${ }^{1}$ Zob. Artur Patek, Żydowscy zesłańcy na Mauritius 1930-1945 [w:] Amerykomania. Księga jubileuszowa ofiarowana Profesorowi Andrzejowi Mani, t. 2, red. Włodzimierz Bernacki, Adam Walaszek, Kraków: Wydawnictwo UJ, 2012, s. 667-678.

${ }^{2}$ Zob. Joanna Newman, Nearly the New World. The British West Indies and the Flight from Nazism, 1933-1945, New York: Berghahn, 2019, s. 210-211.

${ }^{3}$ Zob. Referat Ministra Spraw Zagranicznych w sprawie uzyskania pomocy brytyjskiej dla polskich i żydowskich uchodźców z 7 IV 1941 r. [w:] W obliczu Zagłady. Rząd RP na uchodźstwie wobec Żydów 1939-1945, red. Piotr Długołęcki, Warszawa: PISM, 2021, s. 121.

${ }^{4}$ Zob. Archiwum Akt Nowych (dalej AAN), Instytut Hoovera, Ministerstwo Spraw Zagranicznych (dalej MSZ), 529, folder 14, Korespondencja między Foreign Office a MSZ z grudnia 1941 i stycznia 1942 r., b.p.

${ }^{5}$ Zob. Newman, Nearly the New World. The British West Indies and the Flight from Nazism..., s. $210-211$.

${ }^{6}$ Do Giblartar Camp skierowano także w 1942 i 1943 r. grupy uchodźców z Holandii, Luksemburga i Czechosłowacji. Zob. ibidem, s. 218. 
ne przez placówki dyplomatyczne we Francji, Szwajcarii lub Portugalii. Inni jak Juliusz Lichtenberg, przedsiębiorca z Łodzi - znaleźli się na Zachodzie tuż przed wybuchem wojny. Jak wynika z korespondencji i wspomnień, w drodze na Jamajkę towarzyszyło im wyobrażenie, że jest to miejsce, gdzie będą mogli w miarę normalnie - acz tymczasowo - żyć i pracować. Po przybyciu na Jamajkę 8 lutego 1942 r. ostemplowano ich paszporty formułą „Pozwolenie na pobyt w Kingston na Jamajce pod ścisłym nadzorem w oczekiwaniu na wynik dokładnego dochodzenia" ${ }^{\prime}$, po czym przewieziono autobusami kilka kilometrów poza Kingston do obozu utworzonego latem 1940 r. na terenie byłej plantacji trzciny cukrowej Mona, należącej do Jamajskiej Komisji Wodnej ${ }^{8}$. Gibraltar Camp - jak nazwa wskazuje - początkowo był przeznaczony dla obywateli brytyjskich ewakuowanych z Gibraltaru. Obóz, obejmujący 112 drewnianych baraków - każdy składający się z dwóch części, podzielonych cienkimi ściankami działowymi na 28 pokoi - był otoczony płotem z drutu. Na jego obszarze znajdowały się również stołówki i kuchnie, szkoła, szpital, biblioteka, trzy budynki do celów rekreacyjnych, kościół i posterunek straży obozowej. Ta ostatnia oprócz zaprowadzania porządku w obozie miała pilnować obowiązującej godziny policyjnej (od dziesiątej wieczorem do ósmej rano) oraz ścisłego zakazu wchodzenia na teren Jamajczyków tam niezatrudnionych. Komendantem obozu był Ernest Rae, znany były reprezentant Jamajki w krykieta, biznesmen i były wiceburmistrz Kingston. Docelowo Camp Gibraltar mógł pomieścić 9 tys. osób. Jesienią 1940 r. na Jamajce znalazło się 1486 ewakuowanych obywateli brytyjskich - część obozu, w których ich umieszczono, nazwano później Gibraltar Camp I9.

Polscy Żydzi zostali umieszczeni w uprzednio niezamieszkanej części obozu, oznaczonej po ich przybyciu jako Gibraltar Camp II. Oprócz przestrzegania godziny policyjnej mieli zakaz wychodzenia z obozu bez udzielonej przepustki; oznajmiono im również, że warunkiem ich pobytu na wyspie jest niepodejmowanie jakiejkolwiek pracy. Rozczarowanie było ogromne, czego dowodem są publikowane dalej listy wysyłane z Jamajki indywidualnie i przez założony w obozie komitet do Ignacego Schwarzbarta, dziennikarza i przedwojennego posła, członka Rady Narodowej Rzeczypospolitej Polskiej na obczyźnie, których kopię wysyłano do gen. Władysława Sikorskiego, członków rządu RP w Londynie, Winstona Churchilla i premiera Kanady Williama Mackenzie Kinga. „Ewakuowani", jak ich nazywano w oficjalnych dokumentach, a de facto internowani, skarżyli się w nich na „przymusową bezczynność” i „bezpożyteczny tryb życia” oraz szukali możliwości wyjazdu z wyspy, nadzieję upatrując w szansie na uzyskanie wizy kanadyjskiej. „Mieliśmy okropne poczucie straty, czuliśmy, że nigdzie nie

\footnotetext{
${ }^{7}$ Fred Mann, A Drastic Turn of Destiny, Toronto: The Azrieli Foundation, 2009, s. 250.

${ }^{8}$ Obecnie jest to teren kampusu Uniwersytetu Indii Zachodnich.

${ }^{9}$ Diana Cooper-Clark, Dreams of Re-Creation in Jamaica: The Holocaust, Internment, Jewish Refugees in Gibraltar Camp, Jamaican Jews and Sephardim, Altona: FriesenPress, 2017, s. 10 i n.
} 
przynależymy" - wspominała po latach Miriam Stanton (Sandzer) ${ }^{10}$. Jedynymi osobami, które miały pozwolenie na regularne opuszczanie obozu - i regularne zajęcie - byli nastolatkowie, uczęszczający do lokalnych szkół w Kingston. Prześwietlano również przeszłość internowanych w obawie przed ewentualnymi szpiegami ${ }^{11}$, czego dowodem jest przypadek Dawida Berkenbauma, internowanego w obozie z żoną, wobec których lokalna policja kryminalna prowadziła śledztwo, podejrzewając ich o komunizm.

Kwestia pracy była tylko wierzchołkiem góry lodowej - jak wynika z listu Juliana Lichtenberga, przy przyjeździe skonfiskowano internowanym pieniądze i inne zasoby finansowe, po czym wypłacano im skromne kieszonkowe, więc nawet ci z pozwoleniem na wyjście z obozu nie mieli za co kupić czegokolwiek. Choć warunki w obozie określano jako znośne, Żydzi w Gibraltar Camp mieli sporo problemów z dostosowaniem się do klimatu wyspy (kilkukrotne epidemie dengi ${ }^{12}$ ), a przede wszystkim trudności wynikających ze zderzenia kultur. Wśród tych ostatnich wiele problemów sprawiało jedzenie, przygotowywane z lokalnych produktów i według lokalnych przepisów, w kuchni zaś nie zachowywano koszeru; w rezultacie część rodzin zaczęła gotować sama z powodów religijnych oraz przyzwyczajeń kulinarnych. Kolejna kwestia wiązała się z religią - co prawda w Kingston była synagoga, ale lokalny rabin Henry P. Silverman odwiedził obóz tylko raz, budząc zdziwienie noszeniem koloratki ${ }^{13}$. Wreszcie punktem zapalnym okazały się relacje z władzami obozu, zwłaszcza komendantem Ernestem Rae. Fred Mann pisze o Rae wprost jako tyranie, który kontrolował wszystko - od kupowanych produktów, przez pozwolenia na wyjście, aż do kwestii pomagania w kuchni. Pewnym nie do końca uświadomionym aspektem takiego postrzegania komendanta mogło być też to, że Rae i inni odpowiedzialni za zarządzanie obozem byli czarni ${ }^{14}$.

Internowani byli również skonfliktowani z przebywającym w obozie przedstawicielem HICEM Bernardem Glasscheibem, który opiekował się nimi także $\mathrm{z}$ ramienia Jointu. W opinii osób osadzonych w Gibraltar Camp Joint, HICEM i inne organizacje żydowskie niewystarczająco reprezentowały ich interesy -

${ }^{10}$ Ibidem, s. 47.

${ }^{11}$ Taki był zresztą oficjalny powód, który podano internowanym jako przyczynę internowania w obozie (Mann, A Drastic Turn of Destiny...., s. 245).

${ }^{12}$ Wirusowa choroba tropikalna przenoszona przez komary z rodziny Aedes; objawy obejmują wysoką gorączkę, wysypkę, bóle głowy, mięśni i stawów, a w niektórych przypadkach (notowane od lat pięćdziesiątych XX w.) gorączkę krwotoczną i wstrząs.

${ }^{13}$ Mann, A Drastic Turn of Destiny, s. 261.

${ }^{14}$ Uwagę na to zwracał ambasador Jan Ciechanowski w depeszy do MSZ z 21 VIII 1942 r. (AAN, Instytut Hoovera, MSZ, 529, folder 14, b.p.). Kwestia koloru skóry zawiadujących obozem miała być też powodem odrzucenia Camp Gibraltar jako miejsca dla ewakuowanych przez komisję z Malty, wizytującą obóz w 1940 r. (Rebecca Tortello, Gibraltar Camp, „The Jamaica Gleaner", 7 XI 2005, https://old.jamaica-gleaner.com/pages/history/story0069.html, dostęp 14 IX 2021 r.). 
zwłaszcza że Joint chciał wykorzystać ewakuację polskich Żydów jako sukces propagandowy. $\mathrm{W}$ artykułach $\mathrm{w}$ amerykańskiej prasie przedstawiano ich nie jako „internowanych”, lecz właśnie jako „ewakuowanych”, którzy na Jamajce znaleźli ratunek dzięki Jointowi, co spotkało się z dość ostrą reakcją przebywających w Gibraltar Camp ${ }^{15}$. Poprzez kontakty rodzinne oraz listy do redakcji gazet próbowali oni sprostować narrację o pobycie w raju jako emigranci i wyjaśnić, że są tam internowani.

Wysyłane przez umieszczonych na Jamajce Żydów listy do Londynu i Stanów Zjednoczonych spowodowały także reakcję władz polskich, czego dowodem jest korespondencja między ministrem spraw zagranicznych Edwardem Raczyńskim i Janem Ciechanowskim, ambasadorem RP w Waszyngtonie. Ciechanowski przekazywał do Londynu wieści od Jointu; w depeszy szyfrowej z 21 sierpnia 1942 r. pisał o niezadowoleniu uchodźców i ich skargach oraz sugestii Jointu, by grupę przenieść do Kanady ${ }^{16}$. W odpowiedzi wysłanej tydzień później Raczyński zawiadamiał, że owszem, do Londynu również doszły pisma ze skargami; MSZ miało zawiadomić Foreign Office, które zwróciło się do gubernatora Jamajki, „by rozważył życzliwie postulat większej swobody ruchów dla obywateli polskich i zatrudnienia ich". Minister spraw zagranicznych dodawał jednak:

Według informacji, jakie posiada MSZ, element uchodźczy na Jamajce - poza kilku osobami - nie jest dodatni. Tym też należy zapewne tłumaczyć ich pretensje i skargi. Mieli oni trudności w uzyskaniu w czasie pobytu w Portugalii jakichkolwiek wiz, dlatego też władze polskie widziały się zmuszone podjąć starania o azyl dla nich na terenach brytyjskich, by stworzyć sobie możliwości uzyskania wiz portugalskich dla wartościowych grup z Francji. Cała ta grupa mieszkała przed wojną poza granicami Polski, na ogół nie zna języka polskiego i miała luźny związek z Polską. Z tych przyczyn dość trudno byłoby mi pójść po linii sugestii Joint'u, by zabiegać o azyl dla całej grupy w Kanadzie, szczególnie wobec kategorycznie negatywnego stanowiska Rządu Kanady [w kwestii] przyjęcia dalszych grup polskich uchodźców Żydów ${ }^{17}$.

Jasno z tego pisma wynika, że dla MSZ sprawa była prosta - internowani znaleźli się na Jamajce, bo trzeba było gdzieś znaleźć dla nich miejsce, choć nie był to „pozytywny element”, a ewentualne działania w sprawie wydostania internowanych z Gibraltar Camp ograniczały się do prośby skierowanej do Foreign Office, napływające skargi określono zaś jako „wygórowane żądania” (lub - jak w piśmie MSZ do ambasady w Waszyngtonie z 8 stycznia 1943 r. - „fałszywe

${ }^{15}$ Zob. Newman, Nearly the New World. The British West Indies and the Flight from Nazism..., s. 221 i nast.

${ }^{16}$ AAN, Instytut Hoovera, MSZ, 529, folder 14, Depesza Jana Ciechanowskiego do MSZ z 21 VIII 1942 t., b.p.

${ }^{17}$ Ibidem. 
przedstawienia sytuacji”18). Ponadto Raczyński nadmieniał, że poprosił organizacje żydowskie o „powstrzymanie skarg”, gdyż może to zniweczyć plany ewakuacji na Jamajkę polskich Żydów z Tangeru (do której zresztą nie doszło). Żydzi w Gibraltar Camp zostali więc niejako pozostawieni sami sobie, a zajmować się nimi mieli ci, którzy zaoferowali ich utrzymanie - czyli Joint. Niemniej z powodów formalnych przebywających na Jamajce Żydów objęto opieką konsulatu RP w Hawanie. W raporcie do MSZ z września 1943 r. konsul Witold Dębicki powtarzał nieprzychylną opinię Raczyńskiego o internowanych i pisał bez ogródek:

Dalsze me informacje potwierdzają opinję ministerstwa o małej wartości elementu uchodźczego na Jamajce. Z tym samym spotykam się od początku mego urzędowania na Kubie. Olbrzymia większość uchodźców Żydów [...] ma bardzo luźny związek z Polską. Pozatym jest to element nie mogący dostosować się ani do klimatu tropikalnego, ani do tutejszych warunków życia. Stąd stałe ich pretensje i niepokój graniczący częstokroć z histerją [...]. Uchodźcom Żydom ciąży przede wszystkim pobyt w obozie, w skupisku własnym, bez możności obracania się $w$ atmosferze miejskiej, zajmowania się interesami lub choćby korzystania z kin, kawiarni itp. ${ }^{19}$

Ponieważ obawiano się, że skargi internowanych spowodują złe wrażenie i zarzuty wobec rządu RP, Dębicki proponował mimo wszystko wyjazd na Jamajkę, aby tam w rozmowach „postarać się wpłynąć na odprężenie atmosfery”. Opieka konsularna ograniczała się jednak głównie do załatwiania spraw paszportowych - przedłużania ich ważności lub wydawania nowych dokumentów. Z cytowanych powyżej pism MSZ i Dębickiego wynika, że polscy Żydzi na Jamajce byli traktowani jako de facto obcy (ów „luźny związek”), ale należało się nimi zająć ze względów formalnych, choć w opinii urzędników sprawiali polskim władzom więcej kłopotów niż mogliby im przysporzyć pożytku. Żądania opieki, interwencji, relokacji czy poprawy warunków wyrażane w listach trudno uznać za niepokoje graniczące $\mathrm{z}$ histerią.

Części internowanych polskich Żydów (około 25 osób) posiadających wizy innych krajów udało się uzyskać zwolnienie z obozu w 1942 i 1943 r. i wyjechać z Jamajki; reszta dzięki staraniom Jointu opuściła Gibraltar Camp na przełomie 1944 i 1945 r., choć czternaście osób z tej grupy przebywało na Jamajce jeszcze jesienią $1947 \mathrm{r}^{20}$

Prezentowany tu niepublikowany wcześniej wybór listów, które internowani na Jamajce kierowali do Ignacego Schwarzbarta, pochodzi z Archiwum Yad Vashem, zespół M.2 (Archiwum dr. Ignacego Schwarzbarta), sygn. 403. Oprócz

${ }^{18}$ AAN, Instytut Hoovera, MSZ, 545, folder 15, Pismo MSZ do Ambasady RP w Waszyngtonie z 8 I 1943 r., b.p.

${ }^{19}$ Raport z 14 IX 1943 r., cyt. za: W obliczu Zagłady. Rząd RP na uchodźstwie wobec Żydów..., s. 462-463. W cytacie zachowano oryginalną pisownię.

${ }^{20}$ Newman, Nearly the New World. The British West Indies and the Flight from Nazism..., s. 243. 
korespondencji wysyłanej z Gibraltar Camp do Londynu (osiem listów i pięć telegramów, poza jednym wyjątkiem pochodzących z 1942 r. - w tym kopie pism wysyłanych do innych adresatów, m.in. premiera Władysława Sikorskiego i Winstona Churchilla) zespół ten zawiera pojedyncze listy i telegramy z lat 1942-1944 w sprawie przebywających w Gibraltar Camp, wymieniane między Schwarzbartem a United Congregation of Israelites na Jamajce (informujące o przybyciu grupy, z prośbą o objęcie jej opieką) oraz z Ministerstwem Pracy i Opieki Społecznej RP (dotyczące ewakuacji internowanych z wyspy w 1944 r.) ${ }^{21}$.

\section{Listy internowanych na Jamajce}

S. Rosenbaum ${ }^{22}$

Kingston, 28 lutego 1942 Gibraltar Camp 2

Dr. Ignacy Schwarzbart Esq.

Szanowny Panie,

Dziękuję za otrzymany telegram, datowany 21 lutego. Z jego treści jednak rozumiem, że nie jest Pan świadomy warunków, w jakich się znajdujemy. W związku z tym chcę Panu zdać oto krótką relację.

8 lutego przybyliśmy na Jamajkę. Przywieziono nas do Gibraltar Camp, gdzie żyjemy w chatach; około 45 osób na dom podzielony na 28 [pokoi]. Po 8 dniach dostaliśmy pozwolenie na pójście do miasta i swobodne poruszanie się za dnia aż do 10 w nocy.

Choć klimat jest dobry, to trudno nam, pochodzącym z północnych krajów, się do niego przyzwyczaić i bardzo przeszkadzają nam ugryzienia insektów, które w ciągu kilku ostatnich dni spowodowały wśród nas przypadki dengi. Obóz jest położony w odległości 6 mil od Kingston, doskonały pod względem zorganizowania i w pięknym miejscu, najzdrowszym na wyspie. Dyrekcję obozu stanowi Komendant i jego personel; są oni wspaniali i wszyscy robią, co w ich mocy, by zapewnić nam tyle komfortu, ile to możliwe. Jednakże zrozumie Pan nasze uczucia, gdy usłyszeliśmy, że nie przybyliśmy tu jako „imigranci”, ale „ewakuowani” i musimy żyć zgodnie z „Evacuees Defence Regulations”, które zabraniają jakiejkolwiek pracy za zapłatą. Wciąż nie jesteśmy świadomi dokładnych warunków, na jakich się tu znaleźliśmy, jako że te, o których informowano nas w Lizbonie, okazują się fałszywe ${ }^{23}$. Nie możemy uwierzyć, że ktokolwiek pragnąłby, abyśmy

${ }^{21} \mathrm{~W}$ przytaczanych listach zachowano oryginalną pisownię, uwspółcześniono jedynie interpunkcję, by ułatwić ich lekturę.

${ }^{22}$ Urodzony w 1898 r. 6 I 1944 opuścił Jamajkę i udał się na Kubę (AAN, Instytut Hoovera, MSZ, sygn. 154, folder 41, Pismo Foreign Office do Ambasady RP w Londynie z 10 III 1944 r. List w języku angielskim).

${ }^{23} \mathrm{~W}$ podobnym $\mathrm{w}$ treści liście wysłanym tego samego dnia do gen. Sikorskiego Rosenbaum pisał: „Gdy opuszczaliśmy Lizbonę, powiedziano nam, że udajemy się do wolnego kraju 
w tych warunkach żyli do końca wojny. Pańska sugestia, abyśmy poświęcili się pracy wojennej, nie może być zrealizowana w sposób, który miał Pan na myśli. Nasza grupa składa się ze 115 dorosłych (61 mężczyzn i 54 kobiety) i 35 dzieci. Najbardziej doskwiera nam przymusowa bezczynność. Dlatego musimy rozważyć, że nasz pobyt tutaj ma charakter przejściowy i podjąć starania, aby dotrzeć do krajów, gdzie możemy zbudować nowe życie. Powtarzając to, co pisałem w poprzednim liście, i wiedząc, że na Pańskim stanowisku trudno będzie zdobyć dla nas wszystkich zbiorową wizę, mam nadzieję, że uda się Panu wyświadczyć mi przysługę, o którą prosiłem, i wystarać się o niezbędne wizy do Kanady dla moich przyjaciół i dla mnie. [...]

Z poważaniem,

Rosenbaum Szyja [podpis odręczny]

Z języka angielskiego przełożyła Agnieszka Haska

Źródło: AYV, M.2, Archive of Dr. I. Schwarzbart, member of the Polish National Council in Exile, London, sygn. 403, k. 6-7.

Grupa Uchodźców Polskich

Jamajka, 25 sierpnia 1942

Gibraltar Camp 2

IAMAJKA

Do Szanownego Pana

Ignacego Schwarzbarta

Posła przy Rządzie R.P.

w LONDYNIE

Wielmożny Panie Pośle,

Na skutek wzajemnej umowy, jaka zapadła między rządami Angielskim i Polskim, grupa uchodźców polskich w Lizbonie, przybyłych z różnych krajów Europy okupowanych przez najeźdźcę, została umieszczona w obozie Gibraltar Camp na Jamajce.

Pełni ochoty do walki i pracy zdrowi ludzie, którzy przez swoje fachowe znajomości mogą być użyteczni w różnych dziedzinach, spędzają swój drogocenny czas w bezczynności.

Po trzyletniej tułaczce, uciekając z Europy w ogniu, ratując siebie i najbliższych przed obozami koncentracyjnymi hitleryzmu i faszyzmu, znajdujemy się obecnie na ziemi angielskiej, gdzie chcielibyśmy dać z siebie największy wysiłek z naszych umiejętności dla wspólnej sprawy.

jako wolni ludzie, z możliwością zbudowania na nowo naszego życia. Teraz oznajmiono nam, że to zupełnie nie wchodzi w grę" (AYV, M.2, sygn. 403, k. 5). 
Uważalibyśmy się za pasożytów, gdyby to się nie działo przeciw naszej woli, prowadzenie tego bezpożytecznego trybu życia w obozie, podczas gdy z dniem każdym rozszalała wszechświatowa wojna pochłania coraz to więcej ofiar.

Nasze sumienia nie pozostawiają nas w spokoju, jedni walczą i umierają, drudzy pracują i pomagają, a my tu żyjemy bezcelowo.

Jesteśmy z tego powodu w wielkiej depresji moralnej, szczególnie obecnie, kiedy wojna osiąga swój punkt kulminacyjny, a siły fachowe są coraz więcej potrzebne.

Wobec powyższych okoliczności oddajemy się wszyscy do dyspozycji naszego Rządu, jedni do służby czynnej, drudzy do pracy w przemyśle wojennym do Kanady. Jednocześnie zwracamy się do WPana Posła z usilną prośbą o poparcie interwencji u odpowiednich władz i wystaranie się dla nas i naszych rodzin o wizę do Kanady.

W oczekiwaniu rychłej i przychylnej odpowiedzi dziękujemy z góry i kreślimy się z głębokiem poważaniem.

Bojm Jankiel [podpis odręczny]

Bojm Szloma [podpis odręczny]

Fajgenbaum Majer [podpis odręczny]

P.S. Listy tej samej treści wysyłamy do:

Premiera Ministrów Anglji sir Winstona Churchilla

Rady Ministrów naszego Rządu w Londynie

Ministra Opieki Społecznej P[ana] M. [właśc. Jana] Stańczyka

Posła przy Rządzie RP P[ana] [Szmula] Zygielbojma

Premiera Ministrów Kanady sir Makenzie King ${ }^{24}$

[podpisy odręczne]

Federmann Dawid ${ }^{25}$

Eisenberg Henryk ${ }^{26}$

Grinspan Rachmil ${ }^{27}$

Eisenberg Leopold ${ }^{28}$

${ }^{24}$ Właśc. William Lyon Mackenzie King, premier Kanady w latach 1921-1928, 1926-1930 i 1935-1938.

${ }^{25}$ Urodzony 20 I 1885 r. w Będzinie, z zawodu piekarz, w Gibraltar Camp przebywał z żoną Altą (ur. 1887) i córką Zuzi (ur. 1923).

${ }^{26}$ Urodzony 6 VII 1898 r. w Tarnowie, z zawodu fabrykant obuwia.

${ }^{27}$ Urodzony 8 I 1904 r. w Częstochowie, z zawodu fabrykant obuwia, w Gibraltar Camp przebywał z żoną Ryfką (ur. 1907) i córką Beatrice (ur. 1928). 13 VII 1944 r. opuścili Jamajkę i udali się na Kubę (AAN, Instytut Hoovera, MSZ, 154, folder 41, Pismo Foreign Office do Ambasady RP w Londynie z 2 IX 1944 r., b.p.).

${ }^{28}$ Urodzony 26 V 1893 r. w Tarnowie, z zawodu fabrykant bielizny, brat Henryka Eisenberga, w Gibraltar Camp przebywał z żoną Henriettą (ur. 1903). 
Hoch Salomon ${ }^{29}$

Krakowiak Izaak ${ }^{30}$

Krakowiak Jecheskel ${ }^{31}$

Korn Sara ${ }^{32}$

Lipmanowicz Samuel $^{33}$

Lipszyc Aron ${ }^{34}$

Mann Emanuel ${ }^{35}$

Mann Manfred ${ }^{36}$

Milgrom Simon ${ }^{37}$

Oselka Szepsia ${ }^{38}$

Prizel Simon ${ }^{39}$

Tenenbaum Rafael ${ }^{40}$

Wolken Ludwik ${ }^{41}$

Ringer Arthur ${ }^{42}$

${ }^{29}$ Urodzony 24 I 1897 r. w Sanoku, z zawodu krawiec.

${ }^{30}$ Urodzony 19 I 1902 r. w Warszawie, z zawodu mechanik precyzyjny, w Gibraltar Camp przebywał z żoną Hindą (ur. 1911).

${ }^{31}$ Urodzony 30 III 1903 r. w Warszawie, z zawodu „specjalista w kauczuku”, brat Izaaka Krakowiaka, w Gibraltar Camp przebywał z żoną Zyslą (ur. 1910). 29 X 1943 r. opuścili Jamajkę i udali się do USA (AAN, Instytut Hoovera, MSZ, 154, folder 41, Pismo Foreign Office do Ambasady RP w Londynie z 14 II 1944 r., b.p.).

${ }^{32}$ Urodzona 18 XII 1902 r. w Majdanie, z zawodu szlifierka diamentów. 8 XII 1943 r. opuściła Jamajkę i udała się na Kubę (ibidem).

${ }^{33}$ Urodzony 26 V 1896 r. w Wadowicach, z zawodu fabrykant wyrobów skórzanych, w Gibraltar Camp przebywał z żoną Saroltą (ur. 1902), synem Adolfem (ur. 1925) i córką Reginą (ur. 1928).

${ }^{34}$ Urodzony 16 III 1901 r. w Krzeczowie, z zawodu tapicer dekorator, w Gibraltar Camp przebywał z żoną Haną (ur. 1908) i synem Henrykiem (ur. 1937). 17 XII 1943 opuścili Jamajkę i udali się na Kubę (AAN, Instytut Hoovera, MSZ, 154, folder 41, Pismo Foreign Office do Ambasady RP w Londynie z 10 III 1944 r., b.p.).

${ }^{35}$ Urodzony 14 IV 1889 r. w Wiedniu, zawód - „wyrób sztanc”, w Gibraltar Camp przebywał z żoną Zeldą (ur. 1896) i synem Fredem.

${ }^{36}$ Syn Emanuela i Zeldy Mannów, ur. 28 II 1926 r. w Lipsku.

${ }^{37}$ Urodzony 14 II 1893 r. w Skałacie, z zawodu kuśnierz.

${ }^{38}$ Urodzony 15 V 1889 r. w Szydłowie, z zawodu technik tartaczny.

${ }^{39}$ Urodzony 11 VIII 1913 r. w Lipsku, z zawodu kuśnierz, w Gibraltar Camp przebywał z żoną Ruth (ur. 1915) i córką Annitą. 21 VI 1944 r. opuścili Jamajkę i udali się na Kubę (AAN, Instytut Hoovera, MSZ, 154, folder 40, Pismo Foreign Office do do Ambasady RP w Londynie z 15 VIII 1944 r., b.p.).

${ }^{40}$ Urodzony 14 I 1895 r. w Warszawie, z zawodu ślusarz, w Gibraltar Camp przebywał z żoną Hanni (ur. 1909), córką Różą (ur. 1935) i synem Norbertem (ur. 1942). 2 VI 1944 r. opuścili wyspę i udali się na Kubę (AAN, Instytut Hoovera, MSZ, 154, folder 40, Pismo Foreign Office do Ambasady RP w Londynie z 1 VIII 1944 r., b.p.).

${ }^{41}$ Urodzony 15 VIII 1890 r. we Lwowie, z zawodu blacharz-metalowiec.

${ }^{42}$ Urodzony 20 I 1909 r. w Krakowie, z zawodu mechanik kliwer. 
Strickler Izaak ${ }^{43}$

Strickler Dawid ${ }^{44}$

Kiper Jakob ${ }^{45}$

Schipper Samuel ${ }^{46}$

Szulsinger Leib ${ }^{47}$

Grossbaum Simon ${ }^{48}$

Lichtenberg Juliusz

Rozen Mina ${ }^{49}$

Birnbaum Lea ${ }^{50}$

Źródło: AYV, M.2, sygn. 403, k. 23-24.

Juliusz Lichtenberg ${ }^{51}$

Kingston, Jamaica

Do Pana Posła Ignacego Schwarzbarta w LONDYNIE
Kingston, dn. 16-go września 1942 r.

W imieniu grupy Polaków ewakuowanych na Jamajkę pozwoliłem sobie wysłać do Pana Posła dnia 25 sierpnia br. telegram treści następującej:

${ }^{43}$ Urodzony 17 XI 1905 r. w Nowosiołkach, z zawodu tokarz, w Gibraltar Camp przebywał z żoną Laurą (ur. 1914). 9 III 1944 r. opuścili Jamajkę i udali się na Kubę (AAN, Instytut Hoovera, MSZ, 154, folder 41, Pismo Foreign Office do Ambasady RP w Londynie z 24 pismo Foreign Office do Ambasady RP w Londynie z 24 maja 1944 r., b.p.).

${ }^{44}$ Urodzony 21 VIII 1907 r. w Nowosiołkach, z zawodu mechanik precyzyjny, brat Izaaka Stricklera, w Gibraltar Camp przebywał z żoną Roberte (ur. 1912).

${ }^{45}$ Urodzony 12 IX 1903 r. w Warszawie, z zawodu mechanik automobilowy.

${ }^{46}$ Urodzony 22 XI 1899 r. w Waręzi, z zawodu szlifierz diamentów, w Gibraltar Camp przebywał z żoną Reizil (ur. 1899) i synem Harrym (ur. 1935). 3 II 1944 r. opuścili Jamajkę i udali się na Kubę (AAN, Instytut Hoovera, MSZ, 154, folder 41, Pismo Foreign Office do Ambasady RP w Londynie z 11 IV 1944 r., b.p.).

${ }^{47}$ Urodzony 26 VII 1902 r. w Wieluniu, z zawodu szofer, w Gibraltar Camp przebywał z żoną Herminią (ur. 1907). 4 V 1944 r. opuścili wyspę i udali się na Kubę (AAN, Instytut Hoovera, MSZ, 154, folder 40, pismo Macieja Załęskiego do Ministerstwa Pracy i Opieki Społecznej w Londynie z 18 VII 1944 r., b.p.).

${ }^{48}$ Urodzony 28 XII 1892 r. w Brześciu nad Bugiem, z zawodu inżynier elektrotechnik.

${ }^{49}$ Urodzona 9 V 1913 w Monasterczysku, z zawodu krawcowa. 24 XI 1943 r. opuściła Jamajkę i udała się na Kubę (AAN, Instytut Hoovera, MSZ, 154, folder 41, Pismo Foreign Office do Ambasady RP w Londynie z 14 II 1944 r., b.p.).

${ }^{50}$ Urodzona 7 XI 1920 r. w Wiedniu, z zawodu krawcowa, córka Miny Rosen. 24 XI 1943 r. opuściła Jamajkę i udała się na Kubę (ibidem).

${ }^{51}$ Urodzony 1 III 1889 r. w Warszawie, przedsiębiorca budowlany, w Gibraltar Camp przebywał z żoną Reginą. 3 II 1944 r. opuścili Jamajkę i udali się na Kubę (AAN, Instytut Hoovera, MSZ, 154, folder 41, Pismo Foreign Office do Ambasady RP w Londynie z 11 IV 1944 r., b.p.). 
„In name of Polish group evacuated Jamaica beg your kind intervention concerning frozen english banknotes stop each person got definitely ten pounds stop remaining balance about thousand pounds stop Being without means try obtain payment eventually by fractions from competent authorities".

Wobec tego, iż do dnia dzisiejszego nie otrzymaliśmy na powyższy telegram żadnej odpowiedzi, pozwalam sobie w imieniu tejże grupy zwrócić się powtórnie do Pana Posła, dodając bliższe szczegóły.

Otóż nasza grupa została ewakuowana z Lizbony dnia 24-go stycznia br. Znajdujemy się w Campie Gibraltar. Nie mamy prawa pracy. Pieniądze w walucie angielskiej, które uratowaliśmy z Europy i które nam odebrano, stanowią ostatnie nasze grosze. Pozostaliśmy bez środków. W ciągu siedmiu miesięcy naszego pobytu na Jamajce wypłacono nam jednorazowo po $£ 10$ (dziesięć) na osobę.

Przed nagłym wyjazdem z Europy nie mieliśmy możliwości zamiany naszych pieniędzy. Dużo osób z naszej grupy, uciekając z Polski lub Francji, nie wiedziało w ogóle, że za granicą był podany termin wymiany funtów angielskich. Przy wydaniu nam wiz na Jamajkę ani w konsulacie Angielskim ani też w konsulacie Polskim nie zwrócono nam co do tego żadnej uwagi.

Ja, niżej podpisany (posiadający paszport zagraniczny wydany przez Starostwo Łódzkie dnia 12-go sierpnia 1939 r. za No. 4/1356/39), wyjechałem z żoną z m. Łodzi dnia 17-go sierpnia 1939 r. na kurację do Vichy, gdzie wojna nas zaskoczyła. Pozostawiłem w Polsce dziecko swoje oraz cały majątek w nieruchomościach w Łodzi i w Warszawie. Są tacy między nami, którzy służyli w Wojsku Polskim we Francji, i tacy, którzy uciekli z Warszawy dnia 7-go września 1939 r. już podczas bombardowania stolicy. Uratowali się oni w ostatniej chwili, zabierając ze sobą swoje drobne oszczędności.

Wobec powyższych wyjątkowych konieczności i warunków, w jakich grupa nasza obecnie się znajduje, zwracamy się do Pana Posła z uprzejmą prośbą o łaskawą interwencję u władz kompetentnych, by nam wypłacono zatrzymane pieniądze lub ewentualnie spłacono takowe ratami. Prosimy usilnie Pana Posła u łaskawe zainteresowanie się tą tak ważną dla nas sprawą i o łaskawą odpowiedź.

Mamy nadzieję, że władze angielskie zechcą zrozumieć nasze wyjątkowe położenie i że sprawa nasza będzie przychylnie załatwiona.

W oczekiwaniu pomyślnej odpowiedzi kreślę się

Z poważaniem,

J. Lichtenberg [podpis odręczny]

P.S.

Przy okazji prosimy uprzejmie o łaskawe przesłanie nam, o ile to możliwe, gazet i tygodników polskich. Nie mamy bowiem tutaj żadnej lektury polskiej. 
Dawid Berkenbaum

Gibraltar Camp, dn. 26 sierpnia 1942

Gibraltar Camp No 2

Kingston

Jamaica, B.W.I.

WPan Poseł

Dr Ignacy Schwarzbart

45, Queens Court, Queensway

LONDON W.2.

Wielce Szanowny Panie Pośle,

Pozwalam sobie zwrócić się do Niego w poniżej wyłuszczonej sprawie i proszę o łaskawe poświęcenie jej uwagi:

Jestem obywatelem polskim, urodzonym 2 lutego 1890 r. w Kaliszu. Jestem posiadaczem paszportu polskiego no B/72/1/37, wystawionego dn. 17 września 1937 r. w Madrycie.

Począwszy od roku 1932-go mieszkałem w Hiszpanii, gdzie posiadałem warsztat reparacyjny przyrządów biurowych (maszyn do pisania itp.). Po przejęciu władzy przez Franco, zostałem na skutek fałszywego doniesienia o działalności politycznej osadzony wraz z żoną ${ }^{52} \mathrm{w}$ więzieniu. Po upływie 13-tu miesięcy zostałem $\mathrm{z}$ braku jakichkolwiek dowodów winy zwolniony z aresztu, lecz otrzymałem nakaz opuszczenia kraju. (W czasie mego aresztu rozkradziono całkowicie zawartości mego mieszkania i interesu). 0 przebiegu tej sprawy były dokładnie poinformowane polski Konsulat Generalny w Madrycie oraz Konsulat w Barcelonie, które interweniowały, delegowały adwokata dla zajęcia się nią i wystawiły zaświadczenia o moim dobrym prowadzeniu i lojalności politycznej.

Opuściwszy Hiszpanię, przybyłem do Portugalii, gdzie zostałem ponownie aresztowany przez tamtejszą policję i bez podania jakichkolwiek motywów przetrzymany 17 miesięcy, aż do mego wyjazdu na Jamajkę.

Na Jamajkę udałem się w styczniu roku bieżącego, wraz z grupą obywateli polskich z Portugalii, po otrzymaniu odnośnej wizy wydanej przez British Passport Control Office w Lizbonie, na skutek zalecenia Poselstwa Polskiego i na zasadzie odnośnego układu zawartego przez rządy Polski i Brytyjski.

Przybywszy tutaj, zostałem znowu aresztowany przez władze bezpieczeństwa, które po przesłuchaniu mnie i żony oraz zbadaniu naszych dokumentów zwolniły nas po upływie 7-u tygodni. W ubiegłym tygodniu, a więc po upływie nowych blisko 5-u miesięcy, wezwano mnie na przesłuchanie, w czasie którego stawiano mi pytania na temat mojej rzekomej działalności komunistycznej w Hiszpanii przed wojną domową. W wyniku tego przesłuchania pozbawiono mnie prawa wychodzenia na miasto, polecając Dyrekcji Obozu odebranie mi odnośnej legitymacji. Jestem więc właściwie ponownie aresztowany.

\footnotetext{
${ }^{52}$ Perla Tenenbaum, ur. 3 V 1893 r. w Łodzi.
} 
Dotychczas nie wiem, jakie są zarzuty przeciwko mnie i jakiego rodzaju oskarżenie lub podejrzenie na mnie ciąży. Rozumiem, iż faszystowskiej Hiszpanii wystarczyło gołosłowne oskarżenie o komunizm, by przesiedzieć przeszło rok w więzieniu i być poleconym jako komunista policji portugalskiej. Nie rozumiem natomiast, dlaczego tego rodzaju na niczym nie oparty zarzut wystarczy, aby być molestowanym i krzywdzonym na terytorium brytyjskim. (Mam bardzo poważne podejrzenie, iż moje ponowne trudności tutaj są spowodowane mściwą denuncjację osoby mającej do mnie osobistą niechęć i pragnącej w ten sposób naprawić swoją trudną sytuację wobec tutejszych Władz Bezpieczeństwa). Jestem pozbawiony wolności po raz drugi tutaj wraz z żoną, pod zarzutem, którego nie znam. Co więcej: gdyby nawet sugerowana mi działalność komunistyczną była prawdą, to nawet $\mathrm{w}$ tym wypadku nie rozumiem, w jakim to by pozostawało w związku z moją lojalnością stosunku do Wielkiej Brytanji, Polski lub sprawy Aljanckiej.

Jestem byłym żołnierzem polskim, bojownikiem o Niepodległość, kilkukrotnie rannym w kampaniach wołyńskiej i małopolskiej. Posiadam w dowód tego odnośnie dokumenty wojskowe. Zaznaczam, iż wszystkie moje dokumenty polskie oraz zagraniczne, z wyjątkiem paszportów, znajdują się w posiadaniu tutejszych Władz Bezpieczeństwa.

W związku z powyższym zwracam się do Pana Posła, jako Członka Rady Narodowej, z uprzejmą prośbą o zajęcie się sprawą moją oraz mojej żony i przez skontaktowanie odnośnych władz polskich i brytyjskich, spowodowanie wyjaśnienia jej i przywrócenia nam całkowitej wolności, jak i zanulowania wszelkiego dochodzenia przeciwko nam. Dziękując z góry za łaskawy wysiłek w tym kierunku, przepraszam za trud, który Panu Posłowi zadaję i - w oczekiwaniu rychłej cennej odpowiedzi - kreślę się

z wysokim poważaniem

Dawid Berkenbaum [...]

Źródło: AYV, M.2, k. 21-22.

WPan

Dawid Berkenbaum

12 lipca 1943

Gibraltar Camp No 2

Kingston.

Jamaica B.W.I

Szanowny Panie,

w związku z Pańskim listem z dnia 26 sierpnia 1942 i moimi w tej sprawie krokami proszę o wiadomość, jaką jest obecnie pozycja Pana i żony.

$\mathrm{Z}$ poważaniem, Dr I[gnacy] Schwarzbart 
WPan Dr. Ignacy Schwarzbart

Member of the National Council of Poland

LONDON W.2

Wielmożny Panie Doktorze!

List Pana Dra z dnia 12 lipca br. otrzymałem, za który serdecznie dziękuję.

Co do mojej sprawy donoszę, iż pozycja moja i mojej żony jest dotychczas niezmieniona.

Proszę zatem jak najuprzejmiej Pana Dra o dalszą interwencję, za którą z góry serdecznie dziękuję i kreślę się,

z wysokim poważaniem:

[podpis odręczny]

Dawid Berkenbaum

Hut 62, Camp Gibraltar,

KINGSTON, Jamaica

Jamaica, 10 sierpnia 1943

[dopisek odręczny] P.S. Błagam W.P. Dr. o dopomoc nam wydostać się stąd jak najprędzej.

Źródło: AYV, M.2, sygn. 403, k. 33-34.

BIBLIOGRAFIA

Źródła archiwalne

Archiwum Akt Nowych

Archiwum Yad Vashem

Instytut Hoovera, Ministerstwo Spraw Zagranicznych, sygn. 154, 529, 545

M.2, Archive of Dr. I. Schwarzbart, member of the Polish National Council in Exile, London, sygn. 403

\section{Publikacje}

Cooper-Clark Diana, Dreams of Re-Creation in Jamaica: The Holocaust, Internment, Jewish Refugees in Gibraltar Camp, Jamaican Jews and Sephardim, Altona: FriesenPress, 2017.

Mann Fred, A Drastic Turn of Destiny, Toronto: The Azrieli Foundation, 2009.

Newman Joanna, Nearly the New World. The British West Indies and the Flight from Nazism, 1933-1945, New York: Berghahn, 2019.

Patek Artur, Żydowscy zesłańcy na Mauritius 1930-1945 [w:] Amerykomania. Księga jubileuszowa ofiarowana Profesorowi Andrzejowi Mani, t. 2, red. Włodzimierz Bernacki, Adam Walaszek, Kraków: Wydawnictwo UJ, 2012.

Rebecca Tortello, Gibraltar Camp, „The Jamaica Gleaner”, 7 listopada 2005, https://old. jamaica-gleaner.com/pages/history/story0069.html.

W obliczu Zagłady. Rząd RP na uchodźstwie wobec Żydów 1939-1945, red. Piotr Długołęcki, Warszawa: PISM, 2021. 